\title{
BIOTECHNOLOGICAL APPROACHES TO THE PRESERVATION AND USE OF BOVINE OVARIAN CUMULUS-OOCYTE COMPLEXES IN THE SYSTEM OF REPRODUCTIVE TECHNOLOGIES
}

\author{
P. A. Trotskyi ${ }^{1 *}$, O. V. Shcherbak ${ }^{1}$, I. M. Lyuta ${ }^{2}$ \\ ${ }^{1}$ Institute of Animal Breeding and Genetics n.a. M.V. Zubets of NAAS, \\ off. 225, 1, Pohrebniaka Str, Chubynske village, Boryspil district, Kyiv region, Ukraine, 08321 \\ ${ }^{2}$ Mykolaiv National Agrarian University, \\ 9, Georgiy Gongadze Str., Mykolaiv, Ukraine, 54020
}

E-mail: trotskiy_pa@ukr.net",ov19792006@gmail.com,liutaim@mnau.edu.ua

Received May 27, 2020 / Received November 03, 2020 / Accepted November 20, 2020

\begin{abstract}
Aim. To study the effect of different concentrations of ethylene glycol and glycerin in equilibration and vitrification solutions on 1) the viability and further development of frozen-thawed bovine ovarian cumulus-oocyte complexes (COCs), cryopreserved by vitrification method, 2) on the effectiveness of inseminating mature oocytes, obtained from them, and 3) on the formation of embryos. Methods. Biotechnological, cryobiological, morphological, cytogenetic, and statistical methods, as well as methods of statistical data processing were used in the research. Results. The results of experimental studies on the effect of different concentrations of ethylene glycol and glycerin in the equilibration solution during cryopreservation of bovine ovarian COCs $(n=502)$ on their viability and further development after freezing-thawing are presented. We also show the results of the comparative analysis of cryoresistant properties of bovine ovarian COCs $(\mathrm{n}=560)$ using different concentrations of ethylene glycol and glycerin, as cryoprotectants, in the vitrification solution in terms of the viability and maturation of the oocytes, which originated from these COCs, up to metaphase II of meiosis. A comparative analysis of the application of ethylene glycol and glycerol in different concentrations for the equilibration and vitrification solutions in cryopreserving bovine ovarian COCs $(n=220)$ demonstrated a relationship between the level of concentration of these cryoprotectants and the number of embryos after in vitro insemination of mature gametes, obtained from these frozen-thawed COCs. Conclusions. It was found that the use of $25 \%$ ethylene glycol and $5 \%$ glycerin in the equilibration solution and $10 \%$ ethylene glycol and $40 \%$ glycerin in the vitrification solution during cryopreservation of bovine ovarian COCs ensures lower toxicity of these solutions and promotes more efficient (up to $14.3 \%$ ) formation and development of embryos after in vitro insemination of mature gametes, obtained from these COCs.
\end{abstract}

Key words: bovine ovarian cumulus-oocyte complexes (COCs), cryopreservation, ethylene glycol, glycerin, equilibration solution, vitrification solution, in vitro maturation, embryo.

DOI: https://doi.org/10.15407/agrisp7.03.054

\section{INTRODUCTION}

The preservation of genetic diversity should be a global priority in animal breeding (Baschenko $\mathrm{M}$ et al, 2017; Polupan Y et al, 2017). However, current methods of preserving in situ are extremely expensive. Therefore, the efforts of many scientists are aimed at elaborating a reliable method of cryopreserving oocytes, ovicells and creating cryobanks of gametes (Mara L et al, 2013). The vitrification of ovarian so-

(C) P. A. TROTSKYI, O. V. SHCHERBAK, I. M. LYUTA, 2020 called cumulus-oocyte complexes (COCs) is a simple and cheap method of preserving biodiversity of the animal gene pool on the cellular level under the impact of low temperatures (Jennifer $\mathrm{R}$ et al, 2011). The success of cryopreserving largely depends on cryoprotectants, protecting the cells from the negative effect of low temperatures and ensuring the transition of the liquid into the glassy form and thus preserving the cells in a viable state (Mahmoud KGM et al, 2010; Satish Kumar et al, 2013; El-Shahat KH et al, 2014; Arcarons N et al, 2019). 
Cryoprotectants include biochemical substances, which play the role of water stabilizers and promote prevention or reduction of changes, occurring during the cryopreservation of biological objects. Current opinions about the selection of cryoprotectants are divided. It is noteworthy that bio-objects manifest different cryoresistance depending on the application of cryoprotectants (Petrushko M, 2017). The understanding of the impact of cryoprotectants on the viability and further development of frozen-thawed cells requires the study on the effect of preservation modes and the composition of the preserving medium which would ensure high viability of the cells and their further development in vitro (Abdel-Gawad E et al, 2016; Qian AR et al, 2019).

The method of cryopreservation and storing at low temperatures is selected individually for each biological object. Its efficiency requires the elaboration of optimal cryopreservation conditions, selection and study of the impact of cryoprotectants on a cell. In the work (Jennifer R et al, 2012) the authors studied the impact of cryoprotectants, used during the vitrification, and the time of thawing bovine ovarian COCs on the viability and further development of embryos.

It should be noted that the toxicity of penetrating cryoprotectants also affects cryoresistant properties of animal COCs prior and after cryopreservation. The toxicity of each cryoprotectant is determined using the results of insemination, and data on embryonic development, chromosome breakages and parthenogenetic activation of oocytes (Edyta A et al, 2011).

The result of the application of COCs cryopreservation is also affected by other factors, for instance, the type of a container, wherein this process is conducted (Khalil W et al, 2014), and the diversity of COC nature (Ortiz-Escribano N et al, 2016).

Besides cryopreservatives, a great role in cryopreservation of gametes is attributed to modifying the cultivation of bovine cumulus-oocyte complexes prior to cryopreservation, which includes clarifying the role of specific components of cultivation media and studying their properties and optimal concentrations (Spricigo JF et al, 2017, Arcarons N et al, 2017, Arcarons N et al, 2019).

The method of vitrification is widely used to cryopreserve the reproductive cells of mammals. However, the efficiency of applying this method to COCs of animals requires optimization of each technological stage. The understanding of the impact of cryopreservation fac- tors on the cells may lead to the elaboration of optimal vitrification methods which would improve the viability indices of frozen-thawed gametes. The cryopreservation of oocytes by vitrification using cryoprotectants provides for storing gametes for rather a long time, ensuring the viability of cells after freezing-thawing.

Different concentrations of cryoprotectants are used in the composition of the equilibration and vitrification solutions to ensure high viability of gametes during the cryopreservation of COCs, since it promotes higher viscosity of the solution without forming intracellular crystals thus preventing irreversible damage during the cryopreservation. At present, many cryoprotectants are used during the cryopreservation of COCs to protect female gametes, including dimethylsulfoxide, glycerin, polyethylene glycol, methanol, propylene glycol, ethylene glycol, saccharose, etc. (Wani NA et al, 2004, Mahmoud KGM et al, 2010, El-Shahat KH et al, 2014, Benjamin P, 2015). The selection of such cryoprotectants as ethylene glycol and glycerin for the experimental studies on cryopreservation of bovine COCs is conditioned by the fact that their application is most common among researchers, working with COCs and bovine embryos (Jennifer R et al, 2012, Satish Kumar et al, 2016, Abdel-Gawad EMM et al, 2016); relative simplicity of their preparation and use of equilibration and vitrification solutions for the procedure of saturation and removal of cryoprotectants and positive experimental results on the application of these cryoprotectants while freezing-thawing and further developing bovine embryos at the pre-implantation stages, obtained both in vivo and in vitro.

A wide spectrum of cryoprotectant concentrations in the vitrification solution is currently used in the experimental studies on cryopreservation of both bovine embryos and COCs (Ortiz-Escribano N et al, 2016, Micenyk AC et al, 2019). The most common method is the application of a certain concentration of cryoprotectants in the equilibration or vitrification solutions. The selection of cryoprotectant concentration is conditioned by different response of reproductive cells thereto. The effect depends both on temperature and the degree of permeability of the plasmatic membrane for this cryoprotectant. Thus, the studies were aimed at comparative analysis of the impact of the increase in the concentrations of ethylene glycol and the decrease in the concentrations of glycerin in the equilibration $(30 \%)$ and vitrification $(50 \%)$ solutions on the viability of bovine frozen-thawed COC which had been cryopreserved by the vitrification method for the pur- 
pose of further use of the study results in the system of reproductive technologies.

\section{MATERIALS AND METHODS}

Bovine ovarian COCs were the object of the experimental study, using ethylene glycol (33068 "Fluka") and glycerol (G 2025 "Sigma"). These were obtained by cutting visible antral follicles by a sterile blade, washing them with Dulbecco's medium, taking them with Pasteur's pipette, and estimating their morphological features with a microscope (MБC-9 USSR). COCs with dense or partially puffy cumulus and with oocytes of homogeneous fine grained ooplasm and undamaged transparent envelope were used for further study. Prior to freezing, $n=1282 \mathrm{COCs}$ were treated with the equilibration solution (10 $\mathrm{min})$, then transferred into the vitrification solution (30 s). The cryopreservation of bovine COCs was done in transparent $0.25 \mathrm{ml}$ straws (ART.NR: 13407/3010 "Minitube"). The equilibration and vitrification solutions were prepared on Dulbecco's phosphate-buffered saline (D 5773 "Sigma-Aldrich") with the addition of $20 \%$ bovine blood serum (F 7524 "Sigma"), previously inactivated at $56{ }^{\circ} \mathrm{C}$ for $30 \mathrm{~min}$. The removal of cryoprotectants after thawing COCs was done by transferring them into the solution of 1.0 M saccharose for $10 \mathrm{~min}$. The cryopreservation of bovine COCs and the removal of cryoprotectants was conducted by the improved method of S. I. Kovtun et al., 2010) (Kovtun et al, 2010).

Then COCs were washed with medium 199 (M 2520 "Sigma-Aldrich") three times, estimated by the morphological features, and transferred into $1 \mathrm{ml}$ of the medium for maturing. It was used to cultivate COCs in four-well plates for $27 \mathrm{~h}$ at the temperature of $38.5^{\circ} \mathrm{C}$ in the atmosphere with $5 \% \mathrm{CO}_{2}$ in the air in the drops of medium 199 with $10 \%$ previously inactivated bovine blood serum, $2.5 \mu \mathrm{g} / \mathrm{ml}$ of follicle-stimulating hormone, $1.0 \mu \mathrm{g} / \mathrm{ml}$ estradiol, $2.5 \mathrm{IU} / \mathrm{ml}$ luteinizing hormone, $2.0 \mathrm{mM}$ sodium pyruvate, $2.92 \mathrm{mM}$ calcium lactate, $40 \mu \mathrm{g} / \mathrm{ml}$ gentamicin (Kovtun et al, 2010).

After in vitro cultivation of COCs, ovicells were subjected to cytogenetic analysis to study the impact of different concentrations of ethylene glycol and glycerin in the equilibration $(n=502)$ and vitrification $(n=560)$ solutions. The cytogenetic preparations were prepared by the method of Tarkowski A.K. (Tarkowski A, 1966) and stained with $2.0 \%$ Giemsa (32884 "Fluka") staining and studied with the microscope (Jenaval "Carl Zeiss"). After maturing in vitro, the remaining ( $\mathrm{n}=$ $=316$.) ovicells, obtained from native (control group) $(n=96)$ and frozen-thawed $(n=220)$ COCs, were sub- jected to the insemination in vitro using frozen-thawed bull semen. The capacitation of sperm cells was done using heparin $(100 \mathrm{un} / \mathrm{ml})$ by the method of Parrish et al (Parrish J et al, 1989). The ovicells were inseminated in vitro with frozen-thawed bull semen in the concentration of $1-5 \times 10^{7}$ spermia per $1 \mathrm{ml}$. The simultaneous incubation of ovicells and sperm cells was done in the thermostat at $38.5^{\circ} \mathrm{C}$ in the atmosphere with $5 \% \mathrm{CO}_{2}$ in the air in the drops of Fert-TALP medium (Parrish $\mathrm{J}$ et al, 1988). After 12-18 h of simultaneous incubation of sperm cells and ovicells, possible zygotes were washed from sperm cells which had stuck to the transparent envelope and transferred to CDM medium for further cultivation.

The cytogenetic preparations of the embryos, obtained after inseminating the ovicells in vitro, were prepared by the method of Ushijima M et al (1988) (Ushijima $\mathrm{M}$ et al, 1988). The statistical processing of the data was conducted by the method of G. F. Lakin (1990) using criterion $\chi^{2}$ using the software package $\times 7$, version 2.0.0.9.

\section{RESULTS}

The results of using different concentrations of ethylene glycol and glycerin in the equilibration solution while cryopreserving bovine ovarian COCs are presented in Figure 1. In the experiment variants A-E we used gradual increase in the concentration of ethylene glycol from 5 to $25 \%$ and respective decrease in the concentration of glycerin from 25 to $5 \%$ from the total volume of the equilibration solution. The experiment variant $\mathrm{K}$ served as control, where native COCs were cultivated in vitro.

The results of experimental studies demonstrated that the use of $25 \%$ ethylene glycol and $5 \%$ glycerin in the equilibration solution during COCs cryopreservation led to a $16.1 \%$ increase $(\mathrm{p}<0.01)$ in the number of cells which matured to the metaphase- 2 of meiosis and the $13.6 \%$ decrease $(p<0.05)$ in the number of cells with chromosome breakage compared to the variant with $5 \%$ ethylene glycol and $25 \%$ glycerin. Thus, at the stage of saturating COCs with the equilibration solution, it is advisable to use ethylene glycol in higher concentration compared to glycerin to increase their cryoresistant properties (preservation) during the cryopreservation.

The results of comparing the impact of increasing the concentration of ethylene glycol in the vitrification solution from 10 up to $40 \%$ and decreasing the concentration of glycerin from 40 down to $10 \%$ respectively 
during the cryopreservation of bovine ovarian COCs on the percentage of oocytes which matured to metaphase- 2 and the percentage of those with chromosome breakage are presented in Figure 2.

The comparative analysis of the application of cryoprotectants in the vitrification solution demonstrated that cryoresistance of the gametes of cows was higher in group A, where $10 \%$ ethylene glycol and $40 \%$ glycerin were used, which is evident in the increased number of ovicells that matured to metaphase-2 of meiosis (Fig. 3) (up to $65.6 \%)(p<0.05)$ and the decreased number of ovicells with chromosome breakage (down to $27.8 \%$ ). In group $\mathrm{B}$, where the composition of the vitrification solution was $20 \%$ ethylene glycol and $30 \%$ glycerin, $63.8 \%$ matured to the stage of metaphase- 2 of meiosis, and the number of ovicells with chromosome breakage was $25.5 \%$. In group E, where the composition of the vitrification solution was $25 \%$ ethylene glycol and $25 \%$ glycerin, these numbers were 59.1 and $29.5 \%$ respectively, and in group D with $30 \%$ ethylene glycol and $20 \%$ glycerin -55.2 and $31.3 \%$ respectively. In group E, when the content of ethylene glycol was increased up to $40 \%$ and the content of glycerin was decreased down to $10 \%$, the number of ovicells that matured to metaphase- 2 decreased (down to $50.5 \%)(p<0.05)$ and the number of ovicells with chromosome breakage increased (up to $33.3 \%$ ).

The results of experiments on in vitro inseminating bovine frozen-thawed ovicells, which had matured in vitro and had then been cryopreserved using two selected concentrations of ethylene glycol and glycerin that demonstrated the highest and lowest cryoprotective effect in our studies, are presented in Table.

It was determined that in group A, where the equilibration solution contained $5 \%$ ethylene glycol $+25 \%$ glycerin, and the vitrification solution - $40 \%$ ethylene glycol $+10 \%$ glycerin, the total index of zygote (Fig. 4) division after insemination in vitro and further cultivation for $96 \mathrm{~h}$ was $6.5 \%$. As for group B, where the equilibration solution contained $25 \%$ ethylene glycol $+5 \%$ glycerin, and the vitrification solution $-10 \%$ ethylene glycol $+40 \%$ glycerin, zygote division was observed in $14.3 \%$ cases. In control group $\mathrm{K}$, where native bovine ovarian COCs were used for maturing and inseminating in vitro, the index of division for inseminated zygotes was $40.6 \%$.

\section{DISCUSSION}

Our studies showed that the ratio of ethylene glycol and glycerin concentrations (as cryoprotectants) in the equilibration solution affects the viability of frozen-

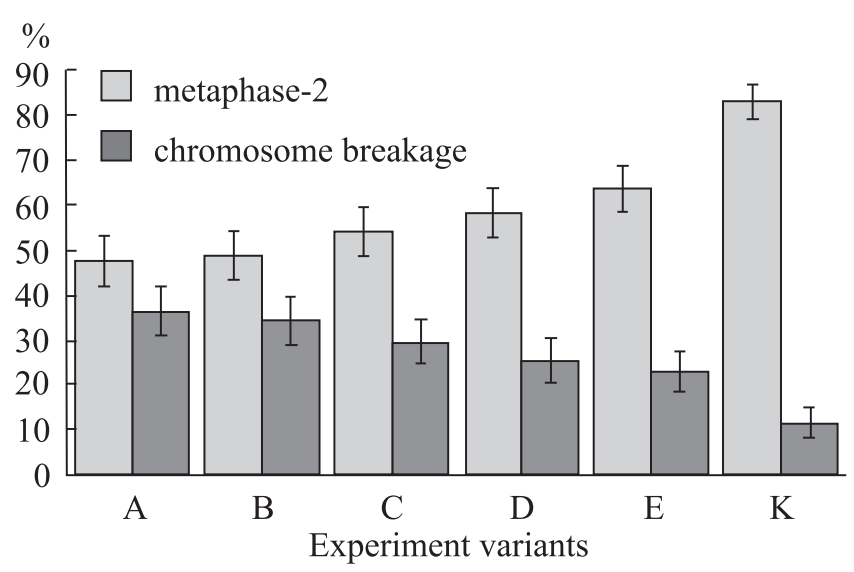

Fig. 1. The impact on survival of different concentrations of ethylene glycol and glycerin in the equilibration solution while cryopreserving bovine ovarian COCs on the percentage of oocytes, which matured to metaphase -2 , and the percentage of those with chromosome breakage

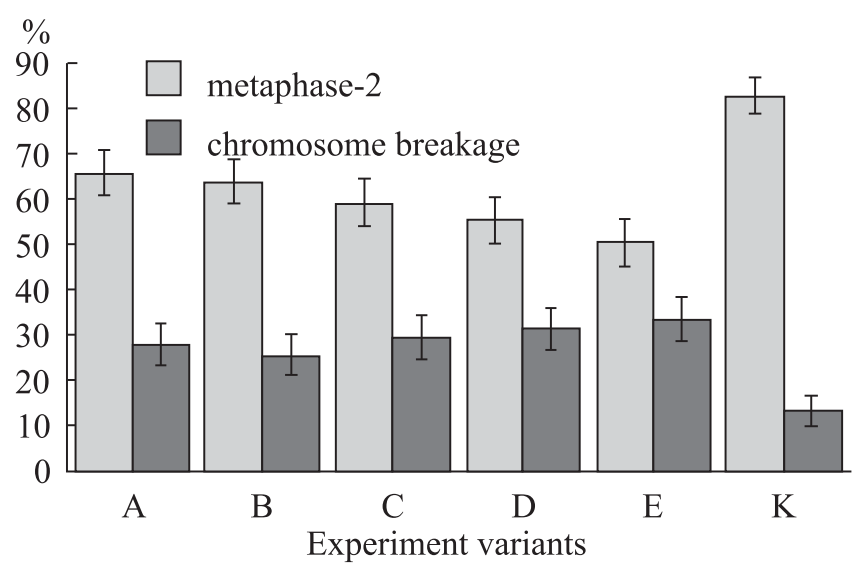

Fig. 2. The impact of using different concentrations of ethylene glycol and glycerin in the vitrification solution while cryopreserving bovine ovarian COCs on the percentage of oocytes, which matured to metaphase-2, and the percentage of those with chromosome breakage

thawed COCs, determined by the indices of the number of ovicells, matured to metaphase- 2 of meiosis, and the number of those with chromosome breakage. The comparison of different schemes of using the cryoprotectants under investigation determined that the decrease in the concentration of ethylene glycol to $10 \%$ and the increase in the concentration of glycerin to $40 \%$ in the total volume of the vitrification solution led to the $15.1 \%$ increase in viable bovine oocytes, which had matured to metaphase- 2 of meiosis.

Some researchers demonstrate that the cryopreservation of bovine ovarian COCs using different concentrations of cryoprotectants has its impact on the development of embryos, obtained after in vitro insemination of frozen-thawed ovicells of cows, which matured in 


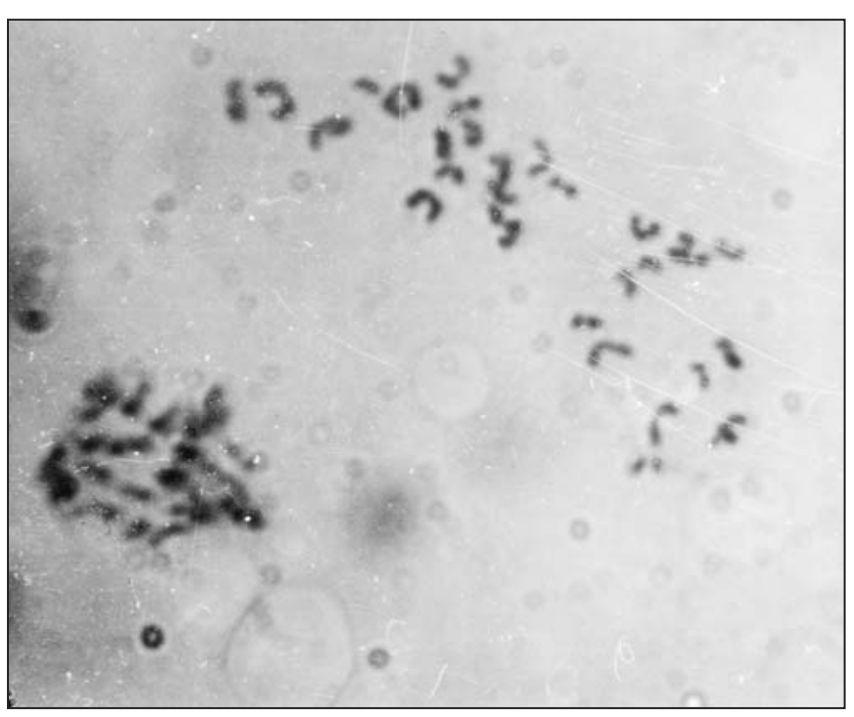

Fig. 3. Air-dried preparation of bovine frozen-thawed oocyte in metaphase-2

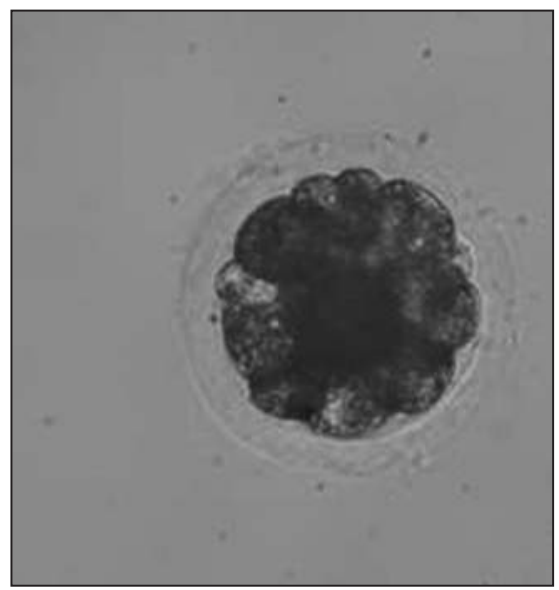

Fig. 4. A bovine embryo obtained after maturing and in vitro inseminating a bovine frozen-thawed oocyte

vitro. However, Abdel-Gawad and Zhou demonstrated the impact of the combination of different cryoprotec- tants in the vitrification medium while freezing mature oocytes which could also affect the maturation of thawed bovine ovarian COCs (Abdel-Gawad EMM et al, 2016; Zhou XL et al, 2010). To enhance the viability of frozen-thawed COCs, some researchers cultivate the cells with substances, increasing their cryoresistance, prior to cryopreservation (Spricigo JF et al, 2017; Arcarons $\mathrm{N}$ et al, 2017). However, for us, the optimization of cryopreservation processes for bovine COCs means searching for simple methods of direct immersing straws with biomaterial into liquid nitrogen. Taking into consideration the data, obtained by us on the cryopreservation of bovine ovarian COCs with different concentrations and combinations of ethylene glycol and glycerin in the vitrification solution, we believe that the combination of these two cryoprotectants ensures high cryoprotective properties which, in its turn, promotes more comprehensive maturation of thawed oocytes and thus provides for their advantage. This assumption is confirmed in the articles (Abdel-Gawad EMM et al, 2016; Micenyk AC et al, 2019), which demonstrate the increase in the level of maturation and insemination of frozen-thawed oocytes, which matured in vitro, after the complex of cryoprotectants has been used in the vitrification solution. The results of our studies on the impact of cryoprotectants while freezing immature COCs of cows in the vitrification solution are in good agreement with the data, obtained by Chaves DF et al, 2017. However, while cryopreserving mature COCs, the authors of these articles obtained more embryos after vitrification as compared to cryopreservation of immature COCs.

Thus, the use of different concentrations of such cryoprotectants as ethylene glycol and glycerin in the equilibration and vitrification solutions ensure both high cryoprotective properties and lower toxicity of the equil-

The results of cultivating the in vitro inseminated frozen-thawed ovicells of cows, which had been cryopreserved using two sets of concentrations of ethylene glycol and glycerin which gave the highest and the lowest cryoprotective effect in our hands

\begin{tabular}{|c|c|c|c|c|c|c|c|c|c|c|c|c|c|}
\hline \multirow{3}{*}{$\begin{array}{l}\text { Expe- } \\
\text { riment } \\
\text { variants }\end{array}$} & \multicolumn{4}{|c|}{ Solutions } & \multirow{3}{*}{$\begin{array}{c}\text { Insemi- } \\
\text { nated } \\
\text { ovicells, } \\
\text { n }\end{array}$} & \multicolumn{8}{|c|}{ Embryos, found at the stage of cell } \\
\hline & \multicolumn{2}{|c|}{ equilibration } & \multicolumn{2}{|c|}{ vitrification } & & \multicolumn{2}{|r|}{$2-4$} & \multicolumn{2}{|r|}{$5-8$} & \multicolumn{2}{|r|}{$9-16$} & \multicolumn{2}{|r|}{ total } \\
\hline & $\begin{array}{c}\mathrm{EG}, \\
\%\end{array}$ & $\mathrm{G}, \%$ & $\begin{array}{c}\mathrm{EG}, \\
\%\end{array}$ & $\mathrm{G}, \%$ & & $\mathrm{n}$ & $\%$ & $\mathrm{n}$ & $\%$ & $\mathrm{n}$ & $\%$ & $\mathrm{n}$ & $\%$ \\
\hline A & 5 & 25 & 40 & 10 & 108 & 3 & $2.8 \pm 1.6$ & 3 & $2.8 \pm 1.6$ & 1 & $0.9 \pm 0.9$ & 7 & $6.5^{\mathrm{a}} \pm 2.4$ \\
\hline $\mathrm{B}$ & 25 & 5 & 10 & 40 & 112 & 3 & $2.7 \pm 1.5$ & 7 & $6.3 \pm 2.3$ & 6 & $5.3 \pm 2.1$ & 16 & $14.3^{b} \pm 3.3$ \\
\hline K & 0 & 0 & 0 & 0 & 96 & 6 & $6.3 \pm 2.5$ & 10 & $10.4 \pm 3.1$ & 23 & $23.9 \pm 4.3$ & 39 & $40.6^{c} \pm 5.0$ \\
\hline
\end{tabular}

Note: EG - ethylene glycol, G - glycerin. $\mathrm{a}: \mathrm{b}-\mathrm{p}<0.05$; $\mathrm{a}$ : $\mathrm{c} ; \mathrm{b}: \mathrm{c}-\mathrm{p}<0.001$. 
ibration and vitrification solutions which, in its turn, promotes obtaining up to $14.3 \%$ embryos after in vitro insemination of the mature oocytes of thawed COCs.

\section{CONCLUSIONS}

The application of $25 \%$ ethylene glycol and $5 \%$ glycerin in the equilibration solution promoted the increase in the number of viable frozen-thawed gametes up to $63.6 \%$ and the decrease in the number of cells with chromosome breakage down to $22.7 \%$.

It was determined that the application of the combination of cryoprotectants in the equilibration $(25 \%$ ethylene glycol and $5 \%$ glycerin) and vitrification ( $10 \%$ ethylene glycol and $40 \%$ glycerin) solutions ensures less toxicity of these solutions during the cryopreservation of COCs and leads to the $14.3 \%$ increase $(\mathrm{p}<0.05)$ in the number of embryos, obtained after in vitro insemination of thawed gametes.

Adherence to ethical principles. The protocol of experiments was approved by the Scientific council of the Institute of Animal Breeding and Genetics n.a. M. V. Zubets of the National Academy of Agrarian Sciences of Ukraine. All the procedures, related to bioethical handling of animals and their slaughter, were conducted in accordance with the European Convention for the Protection of Vertebrate Animals, Used for Experimental and Other Scientific Purposes, Strasbourg, 1986.

Conflict of interests. The authors declare the absence of any conflicts of interests.

Financing. This study was not financed by any specific grant from financing institutions in the state, commercial or non-commercial sectors.

Біотехнологічні підходи щодо збереження та використання ооцит-кумулюсних комплексів корів у системі репродуктивних технологій

$$
\text { П. А. Троцький }{ }^{1 *}, \text { О. В. Щербак }{ }^{1} \text {, I. М. Люта }{ }^{2}
$$

${ }^{1}$ Інститут розведення і генетики тварин ім. М. В. Зубця

Національної академії аграрних наук України, каб. 225, вул. Погребняка, 1, с. Чубинське,

Бориспільський р-н, Київська обл., Україна, 08321

${ }^{2}$ Миколаївський національний аграрний університет, вул. Георгія Гонгадзе, 9, Миколаїв, Україна, 54020

E-mail: trotskiy_pa@ukr.net,ov19792006@gmail.com, liutaim@mnau.edu.ua

Мета. Вивчити вплив використання різних концентрацій етиленгліколю і гліцерину в еквілібраційному та вітрифікаційному розчинах на життєздатність та подальший розвиток деконсервованих ооцит-кумулюсних комплексів (ОКК) корів, що були кріоконсервовані методом вітрифікації; на результативність запліднення отриманих з них дозрілих ооцитів; на утворення ембріонів. Методи. При проведенні досліджень були використані біотехнологічні, кріобіологічні, морфологічні, цитогенетичні, а також методи статистичної обробки даних. Результати. Наведено результати експериментальних досліджень із вивчення впливу різних концентрацій етиленгліколю і гліцерину в еквілібраційному розчині при кріоконсервуванні ОКК корів $(\mathrm{n}=502)$ на їх життєздатність і подальший розвиток після деконсервації. Проведено порівняльний аналіз кріорезистентних властивостей ОКК корів $(\mathrm{n}=560)$ при використанні різних концентрацій етиленгліколю і гліцерину в якості кріопротекторів у вітрифікаційному розчині на життєздатність та дозрівання до метафази- 2 мейозу отриманих 3 цих ОКК ооцитів. Порівняльний аналіз використання різних концентрацій етиленгліколю і гліцерину в еквілібраційному та вітрифікаційному розчинах при кріоконсервуванні ОКК корів $(\mathrm{n}=220)$ виявив взаємозв'язок між рівнем концентрації цих кріопротекторів та кількістю отриманих зародків після запліднення in vitro одержаних з цих ОКК дозрілих гамет. Висновки. Встановлено, що використання $25 \%$ етиленгліколю і $5 \%$ гліцерину в еквілібраційному та $10 \%$ етиленгліколю і $40 \%$ гліцерину у вітрифікаційному розчинах при кріоконсервуванні ОКК корів забезпечує меншу токсичність цих розчинів та сприяє більш ефективному до 14,3 \% формуванню та розвитоку ембріонів поза організмом після запліднення in vitro одержаних з цих ОКК дозрілих гамет.

Ключові слова. Ооцит-кумулюсний комплекс корів, кріоконсервування, етиленгліколь, гліцерин, еквілібраційний розчин, вітрифікаційний розчин, дозрівання in vitro, ембріон.

\section{REFERENCES}

Abdel-Gawad EMM, Abdel-Halim BR, Helmy NA, Badr $A F$. (2016) Effect of Cryoprotective Solutions, Ethylene Glycol, Dimethyl-sulfoxide and Ficoll 70 with Different Combination Ratios on Vitrification of Bovine Oocytes and Embryos Produced in vitro. Asian J Anim Veterin Advs. 11:608-619. doi: 10.3923/ajava.2016.608.619.

Arcarons N, Morató R, Vendrell M, Yeste M, López-Bejar M, Rajapaksha K, Anzar M, Mogas T. (2017) Cholesterol added prior to vitrification on the cryotolerance of immature and in vitro matured bovine oocytes. PLoS One. 14. doi: 10.1371/journal.pone. 0184714 .

Arcarons $N$, Vendrell-Flotats $M$, Yeste $M$, Mercade E, López-Béjar M, Mogas T. (2019) Cryoprotectant role of exopolysaccharide of Pseudomonas sp. ID1 in the vitrification of IVM cow oocytes. Reprod Fertil Dev. 31(9):1507-1519. doi: 10.1071/RD184477.

Benjamin P. (2015) Cryoprotectant Toxicity: Facts, Issues, and Questions. Rejuvenation Res. 18(5):422-436. doi: 10.1089/rej.2014.1656.

Baschenko MI, Gladiy MV, Polupan YP. et al. (2017) 
Theoretical, methodological, scientific and institutional basics of formation of bank of farm animal genetics resources of the Institute of Animal Breeding and Genetics named after M.V. Zubets of NAAS. Rozveden genet tvaryn. 53:7-14. doi: 10.31073/abg.53.01.

Chaves DF, Corbin E, Almiñana C. et al. (2017) Vitrification of immature and in vitro matured bovine cumulus-oocyte complexes: Effects on oocyte structure and embryo development. Livestock Sci. 199:50-56. doi: 10.1016/j. livsci.2017.02.022.

El-Shahat KH, Hammam AM. (2014) Effect of different types of cryoprotectants on developmental capacity of vitrified-thawed immature buffalo oocytes. Anim. Rep. 11(4):543-548.

Jennifer R. Prentice, Muhammad Anzar. (2011) Cryopreservation of Mammalian Oocyte for Conservation of Animal Genetics. Veterin Med Inter. doi: 10.4061/011/146405.

Khalil WA, Gabr Sh A, Shamiah Sh M. et al. (2014) In vitro Maturation, Fertilization and Embryo Development of Immature Buffalo Oocytes Vitrified by Different Cryodevice Types. Asian J Anim Veterin Adv. 9:428-439. doi: 10.3923/ ajava.2014.428.439.

Kumar S, Gautam SK, Gahlawat SK. (2013) Cryobiological effects of cryoprotectants on morphology of cumulus oocyte complexes (COCs) of sheep using vitrification. Inter J Anim Biotech. 3:14-18. https://inpressco.com/ wp-content/uploads/2014/01/Paper414-18.pdf.

Kovtun SI, Trostky PA, Porkhun MG. (2010) Recommendations on cryopreserving bovine cumulus-oocyte complexes. Chubynske. 30 p.(in Ukrainian).

Lakin GF. (1990) Biometrics. Moscow: High School. 351 p. 138-145. (in Russia).

Mahmoud KGM, Scholkamy TH, Ahmed YF, Seidel GEJr, Nawito MF. 2010. Effect of different combinations of cryoprotectants on in vitro maturation of immature buffalo (Bubalus bubalis) oocytes vitrified by straw and open-pulled straw methods. Reprod Domest Anim, 45:565:571. doi: 10.1111/j.1439-0531.2008.01293.x.

Mara L, Sara Casu, Carta A, Dattena M. (2013) Cryobanking of farm animal gametes and embryos as a means of conserving livestock genetics. Anim Reprod Sci. 138(12):25-38. doi: 10.1016/j.anireprosci.2013.02.006.

Micenyk AC, Gelm YuV, Abakushina EV. (2019) Development of the optimal conditions for vitrification of mammalian cumulus-oocyte complexes. J Physics: Conf Series. doi: 10.1088/1742-6596/1189/1/012036.

Morrell JM, Mayer I. (2017) Reproduction biotechnologies in germplasm banking of livestock species: a review. Zygote. 25(5):545-557. doi: 10.1017/S09671994-17000442.
Ortiz-Escribano N, Smits K, Piepers S. et al. (2016) Role of cumulus cells during vitrification and fertilization of mature bovine oocytes: Effects on survival, fertilization, and blastocyst development. Theriogenology. 86(2):635641. doi: 10.1016/j.theriogenology.2016.02.015.

Parrish JJ, Susko-Parrish J, Winer MA, First NL. (1988) Capacitation of bovine sperm by heparin. Biol Reprod. 38:1171-1180.

Parrish JJ, Susko-Parrish J.L., Handrow R.R. et al. (1989) Capacitation of bovine spermatozoa by oviduct fluid. Biol. Reprod. 40:1020-1025.

Petrushko MP. (2017) Current state of cryopreservation of reproductive cells and embryos. Visny`k NAN Ukrayiny. 7:44-53. doi: 10.15407/visn2017.07.044.

Polupan YP, Basovskiy DM, Rieznykova NL. et al. (2017) Problem of biological diversity conservation of farm animal genetic resources. Rozvedeni Genet Tvaryn. 54:2002208. doi: 10.31073/abg.54.26.

Prentice-Biensch JR, Singh J, Mapletoft RJ, Anzar M. (2012) Vitrification of immature bovine cumulus-oocyte complexes: effects of cryoprotectants, the vitrification procedure and warming time on cleavage and embryo development. Reprod Biol Endocrin. http://www.rbej. com/content/10/1/73.

Sprícigo JF, Morató R, Arcarons $N$, Yeste M, Dode MA, López-Bejar M, Mogas T. (2017) Assessment of the effect of adding L-carnitine and/or resveratrol to maturation medium before vitrification on in vitro-matured calf oocytes. Theriogenology. 89:47-57. doi: 10.1016/j.theriogenology.2016.09.035

Szurek EA, Eroglu A. (2011) Comparison and Avoidance of Toxicity of Penetrating Cryoprotectants. 16. doi: 10. 1371/journal.pone.0027604

Tarkowski AK. (1966) An air-drying method for chromosome preparations from mouse eggs. Cytogenetics, 5:394-400.

Ushijima M, Okuda M, Nakajama T. et al. (1988) Relationship between the cell number and Quality of Day- 8 bovine blastocysts. Proc. 3 rd East Jpn. Soc. Anim. Embr. Trans 9:37-38.

Wani NA, Maurya SN, Misra AK, Saxena VB, Lakhchaura $B D$. (2004b) Effect of cryoprotectants and their concentration on in vitro development of vitrified warmed immature oocytes in buffalo (Bubalis bubalis). Theriogenology, 61:831-842.

Zhou XL, Al Naib A, Sun DW, Lonergan P. (2010) Bovine oocyte vitrification using the Cryotop method: effect of cumulucells and vitrification protocol on survival and subsequent development. Cryobiology. 61(1):66-72. doi: 10.1016/j.cryobiol.2010.05.002. 